\title{
Self-efficacy parenting and nursing stress: Study on mother from spectrum autism children
}

\author{
Andini Iskayanti, ${ }^{1}$ Nurul Hartini ${ }^{2}$ \\ ${ }^{1,2}$ Faculty of Psychology, Universitas Airlangga, Surabaya - Indonesia
}

\begin{abstract}
This study aimed to examine parenting self-efficacy especially in mothers who have children with autism spectrum disorder and who suffer from parenting stress. They showed symptoms of anxiety and depression, which indicated parenting stress. Parenting self-efficacy is predicted to be a factor that can decrease anxiety and depression. There were 45 mothers from the city of Surabaya selected through purposive sampling technique to be the participants of this study. The data were collected through a survey using questionnaires concerning Self-efficacy for Parenting Task Index (SEPTI) and Parenting Stress Index Short Form (PSI-SF). The data analyzed using the statistical parametric of the Pearson product-moment correlation coefficient showed that the correlation coefficient was -0.424 and the significance was 0.004 . It was concluded that high parenting self-efficacy of mothers who have children with autism spectrum disorder correlates with parenting stress.
\end{abstract}

Keywords: autism spectrum disorder; parenting self-efficacy; parenting stress

\begin{abstract}
Abstrak: Penelitian ini mengkaji keyakinan diri menjadi orangtua (parenting selfefficacy) khususnya ibu dengan anak gangguan spektrum autisme dan stres pengasuhan ibu. Ibu yang mengasuh anak dengan gangguan spektrum autisme menunjukkan gejala kecemasan dan depresi sebagai bagian dari indikator stress pengasuhan dan keyakinan diri menjadi orangtua (parenting self-efficacy) diprediksi sebagai faktor yang dapat menurunkan kecemasan dan depresi ibu. Partisipan penelitian berjumlah 45 orang ibu yang memiliki anak dengan gangguan spektrum autisme di Kota Surabaya, yang direkrut melalui teknik purposive sampling. Pengumpulan data dilakukan dengan metode survey menggunakan kuisioner dalam bentuk skala. Skala yang digunakan adalah Self-efficacy for Parenting Task Index (SEPTI) dan Parenting Stres Index Short Form (PSI-SF). Hasil analisis data dengan menggunakan teknik statistik parametrik korelasi Pearson Product Moment menunjukkan koefisien korelasi sebesar -0,424 dan signifikansi 0,004. Artinya, keyakinan diri menjadi ibu dengan anak gangguan spektrum autisme yang tinggi berkorelasi dengan rendahnya stres pengasuhan ibu.
\end{abstract}

Kata Kunci: gangguan spektrum autisme; parenting self-efficacy; stres pengasuhan

Corresponding Author: Nurul Hartini (e-mail: nurul.hartini@psikologi.unair.ac.id) Faculty of Psychology, Universitas Airlangga, Jl. Airlangga 4-6, Surabaya, Indonesia 60286. 


\section{Introduction}

Children with autism spectrum disorders prevalence continue to show an increase. World Health Organization (2013) estimated that there are 1 in 160 children in the world experiencing autism spectrum disorders. The Morbidity and Mortality Weekly Report (MMWR) reported that in the United States, the number of children with autism spectrum disorders showed an increase of 23\% in 2012 compared to 2008 (Baio etal., 2018). Furthermore, the Director-General of Disease Prevention and Control of the Indonesian Ministry of Health, dr. H. M. Subuh, MPPM. On World Autism Day, April 13, 2016, stated that the Center for Disease Control (CDC) in March 2014 mentioned the prevalence of boys with autism spectrum disorders higher than girls (Communication and Community Service Bureau of the Ministry of Health of the Republic of Indonesia, 2016) Diah Setia, Director of Mental Health Development at the Ministry of Health of the Republic of Indonesia, estimates that the number of children with autism spectrum disorders in Indonesia has also shown an increase; there are more than 112,000 children with autism spectrum disorders (Melisa, 2013) and Widodo Judarwanto, pediatricians, estimated that the number of children with autism spectrum disorders reaches 134,000 children (Cahya, 2016).

The cause of autism spectrum disorders cannot be stated with certainty and is multifactorial. Norris (2006) explained that autism spectrum disorders are characterized by structures and chemicals in the brain that are different from children in general. The structure and chemicals in the brain are different in children with autism spectrum disorders when compared to children in general because autism spectrum disorders are neurobiological developmental disorders that caused by genetic vulnerability and triggered by external multi-factors, such as infections (rubella, cytomegalovirus) when the child is still in womb, chemical ingredients (food preservatives, food coloring, food flavorings, and various other food additives), as well as pollutants such as lead, or mercury from mercurycontaminated fish and used as vaccine preservatives (Rachmayanti \& Zulkaida, 2007). Dietert, Dietert, and Dewitt, (2011) also emphasized that autism spectrum disorders are caused by genetic factors, chemicals from the environment, maternal conditions during pregnancy (diet, infection, or stress), drugs, or combination factors, and various other possible factors.

In general, children with autism spectrum disorders showed developmental disabilities in the ability to communicate and build interpersonal relationships and the presence of repetitive behavior. Rodriguez (2011) and Bernier, Raphael, and Gerdts (2010) explained that autism spectrum disorders are disorders of child development that can be identified before the age of three years, even in the first two to three months after birth through delays in communication skills, social interactions, repetitive or repetitive behaviors, and limited interests.

Different conditions in children who have autism spectrum disorders compared to children who develop normally have an impact on parenting. Many parents reported experiencing a crisis phase related to several aspects of their lives, especially those related to childcare. Even some parents reported experiencing high levels of depression, anxiety, decreased mental health, and stress (Lee, Ong, Lee, \& Nazri-AR, 2017; Weiss \& Lunsky, 2011; Weiss, Wingsiong, \& Lunsky, 2014). Stress is a negative psychological condition experienced by parents in children with autism spectrum disorders and is thought to be the result of parents and child interactions. 
Parenting stress will occur when parents believe that they have poor parenting competencies and have anxiety that they are unable to perform their role as parents. Parenting stress hurts parents' beliefs to cope with stressors so that they pose a risk to their mental health.

There are differences in parenting stress based on gender. Mothers with children with autism spectrum disorders show higher parenting stress when compared to parental stress on the father (Dabrowska \& Pisula, 2010; Tehee, Honan, \& Hevey, 2009). The characteristics and limitations of children with autism spectrum disorders require a more intensive approach, parenting, and care that requires parents, especially mothers to provide greater and more specialized time and energy (Daulay, 2016). Also, the quantity and quality of a mother's relationship with a child that is greater than that of a father make the mother exhibit higher physical fatigue and cognitive and emotional anxiety. Parenting stress is characterized by cognitive and emotional stressful assessments that have an impact on behavior when building relationships with children.

Many researchers often correlate the stress of parenting with the confidence of being parents. It was explained that self-confidence in parenthood had a negative correlation with parenting stress. Research by Coleman \& Karraker (1998, 2000, 2003) explained that self-confidence in being parents will cause positive feelings in the parents; Positive parental emotions will bring positive care and this can support the formation of positive child behavior. Conversely, parenting stress negatively impacts the function and role of parents in parenting (Walker, 2000). Furthermore, Hastings \& Brown's research (2002) explained that self-confidence in being parents can mediate the reduction of anxiety and depression in mothers with children with autism spectrum disorders.

The humanistic paradigm believes that strong internal factors in the mother, especially the self-belief of being parents, will be driving the positive behavior of the mother in caring for children with autism spectrum disorders. Strong self-confidence in mothers to do and provide approaches, parenting, care, and education to children following the characteristics and needs of children without any thoughts and feelings of pressure and burden will present positive thoughts and feelings when interacting with children and doing care. Accepting children as they are with the specifics of their needs without rejection and disappointment will be able to facilitate positive relations between parents and children and will encourage the positive development of children.

Based on the explanation above, the research on the role of self-confidence in being parents, especially mothers with children with autism spectrum disorders in the stress of parenting, is expected to provide alternative solutions to provide positive parenting.

\section{Method}

This research is survey research about selfconfidence in being a mother and parenting stress in mothers with children with autism spectrum disorders and in detail about the participants, data collection tools and data analysis will be explained as follows:

A total of 45 participants in this study were recruited through purposive sampling techniques. Each participant signed a statement of the agreement and willingness to become research respondents voluntarily before filling out the questionnaire. The participants' inclusion criteria include: 1) mothers who care for children with 
Autism Spectrum Disorders, children aged 3 to 12 years; 2) domiciled in the City of Surabaya. Participants aged 25 to 47 years (Mean $=36.96$, $\mathrm{SD}=4.65$ ). The majority of participants had an undergraduate education background (57.8\%), served as a housewife (55.6\%), and had 2 children (57.8\%).

This study uses two scales as data collection instruments. First, the adaptation scale of the Self-Efficacy for Parenting Task Index Items (SEPTI). This scale is used to measure the confidence of being a mother in caring for her child who has autism spectrum disorders. SEPTI includes five dimensions of the efficacy of parenting, including (1) discipline (for example, "I am able to make rules that I can discipline my child to be disciplined in various ways"); (2) achievements (for example, "I have done enough to help my child do his schoolwork"); (3) recreation (for example, "I am the parents who can be involved in my child's play when with his friend"); (4) nurturance (for example, "I have fulfilled my own expectations in terms of providing emotional support for my child"); and (5) health (for example, "I am a caring parents when caring for the health of my child"). This measuring device consists of 36 Likert scale items with a range of 1 (very inappropriate) to 6 (very appropriate). Cronbach Alpha reliability estimates produce coefficients of $\alpha=.79$.

Meanwhile, to measure parental stress in participants, this study uses the Parenting Stress
Index - Short Form (PSI-SF) scale by Abidin, (2012). Consisting of 36 items with a Likert scale ranging from 1 (strongly disagree) to 5 (strongly agree). PSI-SF measures stress based on 3 aspects, namely (1) parental distress (for example, "I am not satisfied with the last clothes I bought for myself"); (2) the characteristics of difficult children (for example, "My child seems to cry more often than other children"); and (3) interaction dysfunction (eg, "My child smiles at me less than I expect"). This scale has an Alpha Cronbach reliability coefficient of $\alpha=.87$.

To test the relationship between the two variables, a Pearson correlation test was performed with the help of the SPSS program version 20.0.

\section{Results}

The result of the descriptive analysis of the variables of self-confidence to be parents and parenting stress in mothers with children with autism spectrum disorders are shown in Table 1. The result of descriptive data analysis showed that the variation in self-confidence scores for parents of participants in this study ranged from 59 to 118 with an average value of 86.56 (SD = 14.32). For parenting stress variables, participant scores varied from 134 to 190 with an average score of 164.62 (SD = 13.74). Based on the Shapiro-Wilk test, both variables were found to have normal data distribution.

Table 1.

The Result of Descriptive Analysis

\begin{tabular}{lcccccc}
\hline \multirow{2}{*}{ Variables } & \multirow{2}{*}{ Minimum } & \multirow{2}{*}{ Maximum } & \multirow{2}{*}{ Mean } & \multirow{2}{*}{$\begin{array}{c}\text { std. } \\
\text { Deviation }\end{array}$} & \multicolumn{2}{c}{ Shapiro-Wilk Test } \\
\hline Self-efficacy parenting & 59 & 118 & 86.56 & 14.32 & .98 & 45 \\
Nursing Stress & 134 & 190 & 164.62 & 13.74 & .98 & 45 \\
\hline
\end{tabular}


Furthermore, based on the result of the Pearson correlation test, a significant relationship was found between parental self-confidence and maternal parental stress $\mathrm{r}(45)=-.42, \mathrm{p}<.01$ ). With a negative correlation coefficient, this result indicated that an increase in parental confidence scores is followed by a decrease in maternal stress scores and vice versa, a decrease in parental confidence scores followed by an increase in parental stress scores in mothers with children with autism spectrum disorders.

\section{Discussion}

The Diagnostic and Statistical Manual of Mental Disorders-DSM V (American Psychiatric Association, 2013) explained that the criteria for diagnosis of Autism Spectrum Disorders (ASD) are (a) permanent deficiencies in the development of communication and social interactions including various contexts, which are characterized in behavior as follows: Deficiencies in interpersonal reciprocal social and emotional behavior both verbally and nonverbally which cause children to experience obstacles in establishing, maintaining, and understanding social relationships. (b) Limited in patterns of behavior, interests or activities, and displaying repetitive activities such as fixed and repetitive (stereotypic) motor movements, use of objects or making certain sounds; Emphasizing the similarity of inflexible adherence to routine, verbal and nonverbal behavior; Excessively limited to certain interests and fixated on the intensity of activity or focus on certain objects or things that are abnormal; Too much or too little response to stimulus (reactive to certain sensory or unusual interest in environmental stimulus). (c) Symptoms must be present in the early development period. (d) Symptoms cause significant clinical disturbances in the social field, work, or important daily activities.
Children with autism spectrum disorders are generally characterized by an inability to communicate and interact with other individuals and are very ignorant of the environment outside them so that their behavior seems to have a world of their own and live in their world (World Health Organization, 2016). Characteristics of children with specific needs, including children with autism spectrum disorders can reduce the mental health of parents and families (McCubbin, Sussman, \& Patterson, 2013). Parents of children with autism spectrum disorders showed a decline in mental health, one of which is caused by the stress of parenting. Parenting stress will be experienced by parents when having children with autism spectrum disorders is perceived by parents as an event that is threatening, challenging, or dangerous to their lives and parents respond negatively to physiological, emotional, cognitive, and behavioral aspects (Feldman, 2011).

Parenting stress has a relationship with the characteristics of children. Characteristics of children are difficult at risk of raising parental stress. A study showed that parents with autism spectrum disorder children experience higher levels of parental stress when compared to parents with children who have normal development like children in general (McStay, Dissanayake, Scheeren, Koot, \& Begeer, 2013). Parenting for children with developmental problems, including autism spectrum disorders will make the parenting process more difficult and intensive when compared to parenting for children with normal development. This presents its challenges for parents, especially mothers. Children parenting requires mothers to have the competencies needed to carry out parental roles. Self-confidence in being a mother can lead to positive feelings when interacting with children 
and it can have a positive effect on the development of positive behavior of children (Coleman \& Karraker, 2000). And vice versa, parenting stress gives a bad impact on the function and role of parents on the development of children's behavior (Walker, 2000). In their parenting, parents feel pressured and burdened with the parenting they have, so parents will feel negative emotions when doing their role in parenting so that parents will unwittingly give less positive responses when dealing with children. Parenting stress will risk worsening parents and child relationships so that in the long run parental stress is strongly correlated with children's social, emotional and behavioral development abilities (Ahern, 2004).

The stress of parenting is caused by external and internal factors. External factors include the problematic behavior of children, family integrity, and psychological well-being of mothers, social support, and family income. While internal factors include depression, temperament, personality, and social self-reference cognition - self-referent social cognition which includes self-confidence and self-esteem (Johnston et al., 2003). External factors that are quite strongly correlated with parenting stress according to Mak, Ho, and Law (2007) are socioeconomic conditions. Handling children with autism spectrum disorders requires intensive time and large amounts of money to provide specialized and intensive care for children. Parents with high socioeconomic status and high income have the opportunity to facilitate children by providing quality education and care, and vice versa parents' limited income makes parents unable to provide quality education and care. However, education and caring with high costs to provide support for the improvement of verbal and nonverbal communication skills that can support social interaction skills of children with autism spectrum disorders are not the only variables supporting child development. On another perspective, support for child development can be done by promoting internal factors in parenting and self-confidence in parenthood is predicted to make a large contribution as a form of positive support.

Internal factors of parents in parenting, selfconfidence to be parents play a role in reducing parenting stress. Self-confidence to be a high parent has a high interest in mentoring, caring, tolerating the challenges that arise, and having a positive self-perception about their ability to handle stressors; Parental self-confidence is negatively correlated with feeling overwhelmed by the task of parenting. The result of this study proved that the confidence of being a parent has a significant correlation with maternal parental stress, $r(45)=-.42, p<.01$. The result is consistent with research by Bloomfield and Kendall (2012) which stated that the correlation of selfbelief of being parents with parental stress is negative. Research by Coleman and Karraker (1998, 2000, 2003) also showed that mothers with high levels of parenting stress have low selfconfidence to be parents and conversely mothers with low levels of parenting stress have high parental confidence.

Confidence in being parents is formed by a variety of variables, including acceptance of parents to children, positive reinforcement from children, attachment, social support, especially from partners. The ability of parents to accept their children without any conditions will bring positive emotions to accept the weaknesses and limitations of children. Strengthening of children means that children showed positive development with the presence of parenting and education efforts and guidance provided by parents. Positive reinforcement provided by children through the achievement of the success of the 
intervention sought by parents will bring confidence in parents of their competence in parenting (Kennedy, 2012). The emotional attachment between children and parents can affect the stress of caregiving. Attachment is characterized by closeness and more attention to the child's need to grow and develop and improve the ability to communicate and interact socially. Without attachment, parents will tend to experience parental stress. Social support, especially from couples to parenting, is positively correlated with self-confidence in being a parent. When couples give support to each other to perform their roles as parents, then both will have the confidence to be good parents (Coleman \& Karraker, 2000).

Parental confidence plays a role in reducing parental stress in mothers who have children with autism spectrum disorders, including reducing maternal anxiety and depression. Mother's anxiety and depression in caring for children with autism spectrum are more related to children's behavior problems because children need special handling that takes up their time and energy. Characteristics of children with autism spectrum disorders are often accompanied by aggressive and destructive behavior and an unstable mood. Children can also force their will to do unusual daily activities and are not the same as other children their age. Besides, children are also sensitive to certain tastes and odors. But with self-confidence to be a mother makes the mother continually strive to have competence in parenting, then the mother will be able to care for, educate, and guide children so that children following their capacities can increase their ability to communicate and interact socially in an optimal way. Hence, acceptance of the child as it is needed by the attachment of the parent to the child, partner support for joint of care and reinforcement of the child to increase self-confidence to be a mother.
Self-confidence in being a mother encourages mothers to provide the best things needed by children with autism spectrum disorders to be able to overcome the limitations and weaknesses in the ability to communicate and interact socially and repetitive behavior. Although external factors such as financial support are also an important factor in providing support for the quality of parenting and education of children with the autism spectrum, but the confidence of being parents is an internal factor of the mother that encourages the creativity and perseverance of the mother to carry out appropriate parenting and education processes that are appropriate to the ability owned by the mother. In limited financial support, mothers with high selfconfidence to be parents will try to provide care and education directly to their children without the help of other parties so that children can continue to improve their ability to communicate and interact socially.

Mothers with high self-esteem become parents will try to find and find parenting and education strategies that are right for their children. The mother will try to understand and apply healthy parenting patterns for her children so that gradually the child can build independence so that they can build interpersonal relationships and can improve their quality of life. Children with proper handling are expected to be able to take formal education together with other children their age in an inclusive education setting. Also, certain food diets for children with autism spectrum disorders should be the main concern of mothers in parenting. Various specific needs are understood consciously by the mother and family with maximum efforts to fulfill them and adjust to their capacity and abilities, so parenting in children can be used as part of the roles and tasks of parents without stressed and overwhelmed feelings and thoughts.

Finally, it needs to be stated that this study has weaknesses, among which researchers did not 
verify the diagnosis of autism spectrum disorders in every child of the study subjects. The diagnosis is based on the testimony of a mother who has received a doctor's statement that her child has autism spectrum disorders. Also, the Self-efficacy for Parenting Task Index (SEPTI) measurement tool has never been used in mothers who have children with autism spectrum disorders.

\section{Conclusion}

There is a significant negative relationship between self-confidence in parenthood with parental stress on children with autism spectrum disorder children. The higher the confidence of being a parent, the lower the stress of caregiving that will be experienced by mothers with children with autism spectrum disorders. The opposite is true, when the self-confidence of being a parent is lower, the higher the parenting stress that will be experienced by mothers with children with autism spectrum disorders.

\section{Suggestion}

It is recommended that parents, especially mothers, continue to increase their selfconfidence to be parents by providing parenting and guidance to children following the child's capacity and characteristics and needs. Also, it should be more realistic and rational in determining children's learning outcomes.]

\section{References}

Abidin, R. R. (2012). Parenting Stress Index (3rd ed.). United State of America: Psychological Assement Resources.

Ahern, L. S. (2004). Psychometric properties of the Parenting Stress Index - Short form (North Carolina State University). Retrieved from https://repository.lib.ncsu.edu/bitstream/handle/ 1840.16/2765/etd.pdf?sequence=1\&isAllowed=y

American Psychiatric Association. (2013). Diagnostic and statistical manual of mental disorders (5th ed.). https://doi.org/10.1176/appi.books.9780890425596

Baio, J., Wiggins, L., Christensen, D. L., Maenner, M. J., Daniels, J., Warren, Z., ... Dowling, N. F. (2018). Prevalence of autism spectrum disorder among children aged 8 Years - Autism and developmental disabilities monitoring network, 11 Sites, United States, 2014. MMWR Surveillance Summaries, 67(6), 1-23. https://doi.org/10.15585/mmwr.ss6706a1

Bernier, B., Raphael, R., \& Gerdts, J. (2010). Autism spectrum disorders: A reference handbook. California: ABC-CLIO.

Bloomfield, L., \& Kendall, S. (2012). Parenting self-efficacy, parenting stress and child behaviour before and after a parenting programme. Primary Health Care Research \& Development, 13, 364-372.

Cahya, Y. (2016). Jumlah penyandang autis di Indonesia. Retrieved from Rumah Autis website: https://www.rumahautis.org/artikel/jumlah-penyandang-autis-di-indonesia

Coleman, P. K., \& Karraker, K. H. (1998). Self-efficacy and parenting quality: Findings and future applications. Developmental Review, 18, 47-85.

Coleman, P. K., \& Karraker, K. H. (2000). Parenting self-efficacy among mothers of school-age children: Conceptualization, measurement, and correlates. Family Relations: An Interdisciplinary Journal of Applied Family Studies, 49(1), 13-24. https://doi.org/10.1111/j.1741-3729.2000.00013.x 
Coleman, P. K., \& Karraker, K. H. (2003). Maternal self-efficacy beliefs, competence in parenting, and toddlers' behavior and developmental status. Infant Mental Health Journal, 24(2), 126-148. https://doi.org/10.1002/imhj.10048

Communication and Community Service Bureau of the Ministry of Health of the Republic of Indonesia. (2016). Kenali dan deteksi dini individu dengan spektrum autisme melalui pendekatan keluarga untuk tingkatkan kualitas hidupnya. Retrieved from www.depkes.go.id website: http://www.depkes.go.id/article/view/16041300001/kenali-dan-deteksi-dini-individudengan-spektrum-autisme-melalui-pendekatan-keluarga-untuk-tingkatka.html

Dabrowska, A., \& Pisula, E. (2010). Parenting stress and coping styles in mothers and fathers of preschool children with autism and down syndrome. Journal of Intellectual Disability Research, 54(3), 266-280. https://doi.org/10.1111/j.1365-2788.2010.01258.x

Daulay, N. (2016). Gambaran ketangguhan ibu dalam mengasuh anak autis. Psikohumaniora: Jurnal Penelitian Psikologi, 1(1), 49. https://doi.org/10.21580/pjpp.v1i1.929

Dietert, R. R., Dietert, J. M., \& Dewitt, J. C. (2011). Environmental risk factors for autism. Emerging Health Threats Journal, 4(1). https://doi.org/10.3402/ehtj.v4i0.7111

Feldman, R. S. (2011). Understanding Psychology (10th ed.). New York: McGraw-Hill, Companies, Inc.

Hastings, R. P., \& Brown, T. (2002). Behavior problems of children with autism, parental self-efficacy, and mental health. American Journal on Mental Retardation, 107(3), 222-232. https://doi.org/ 10.1352/0895-8017(2002)107<0222:BPOCWA>2.0.CO;2

Johnston, C., Hessl, D., Blasey, C., Eliez, S., Erba, H., Dyer-friedman, J., ... Reiss, A. L. (2003). Factors associated with parenting stress in mothers of children with fragile X syndrome. Developmental and Behavioral Pediatrics, 24(4), 267-275.

Kennedy, D. (2012). The relationship between parental stress, cognitive distortions, and child psychopatology. Philadelphia College of Osteopathic Medicine.

Lee, J., Ong, S., Lee, V., \& Nazri-AR, F. (2017). Parenting stress among Malaysian parents of children with Autism Spectrum Disorder (ASD). Medicine \& Health, 12(42-55). https://doi.org/ 10.17576/MH.2017.1201.06

Mak, W. W. S., Ho, A. H. Y., \& Law, R. W. (2007). Sense of coherence, parenting attitudes and stress among mothers of children with autism in Hong Kong. Journal of Applied Research in Intellectual Disabilities, 20(2), 157-167. https://doi.org/10.1111/j.1468-3148.2006.00315.x

McCubbin, H. I., Sussman, M. B., \& Patterson, J. M. (2013). Social Stress and the Family: Advances and Developments in Family Stress. New York: Routledge.

McStay, R. L., Dissanayake, C., Scheeren, A., Koot, H. M., \& Begeer, S. (2013). Parenting stress and autism: The role of age, autism severity, quality of life and problem behaviour of children and adolescents with autism. Autism, 18(5), 502-510. https://doi.org/10.1177/1362361313485163

Melisa, F. (2013, April). 112.000 Anak Indonesia Diperkirakan Menyandang Autisme (Harliansyah, Ed.). Retrieved from Republika Online website: https://www.republika.co.id/berita/nasional/umum/ 13/04/09/mkz2un-112000-anak-indonesia-diperkirakan-menyandang-autisme

Norris, S. (2006). Potential Causes of Autism Spectrum Disorders. Ottawa: Parliamentary Information and Research Service.

Rachmayanti, S., \& Zulkaida, A. (2007). Penerimaan diri orang tua terhadap anak autisme dan peranannya dalam terapi autisme. Jurnal Ilmiah Psikologi, 1(1). https://doi.org/10.35760/PSI.2007.V1I1.277

Rodriguez, A. (2011). Autism spectrum disorders. USA: Lerner Publishing Group, Inc. 
Tehee, E., Honan, R., \& Hevey, D. (2009). Factors contributing to stress in parents of individuals with autistic spectrum disorders. Journal of Applied Research in Intellectual Disabilities, 22(1), 34-42. https://doi.org/10.1111/j.1468-3148.2008.00437.x

Walker, A. P. (2000). Parenting stress: A comparison of mothers and fathers of disabled and non-disabled children (University of North Texas). Retrieved from https://digital.library.unt.edu/ark:/ 67531/metadc2686/

Weiss, J. A., \& Lunsky, Y. (2011). The Brief Family Distress Scale: A measure of crisis in caregivers of individuals with autism spectrum disorders. Journal of Child and Family Studies, 20(4), 521-528. https://doi.org/10.1007/s10826-010-9419-y

Weiss, J. A., Wingsiong, A., \& Lunsky, Y. (2014). Defining crisis in families of individuals with autism spectrum disorders. Autism, 18(8), 985-995. https://doi.org/10.1177/1362361313508024

World Health Organization. (2013). Autism spectrum disorders \& other developmental disorders From raising awareness to building capacity. Geneva: WHO Library Cataloguing-in-Publication Data.

World Health Organization. (2016). International statistical classification of diseases and related health problems 10th revision (ICD-10)-WHO version for 2016: Chapter V Mental and behavioral F00-F09. Retrieved from icd.who.int website: https://icd.who.int/browse10/2016/en\#/F00-F09 